\title{
HAS SOUTH AFRICA LIBERALISED ITS TRADE?
}

\author{
LAWRENCE EDWARDS*
}

\section{Abstract}

This paper uses new tariff data to re-evaluate the extent to which South Africa has liberalised its trade from the late 1980s. The paper finds that significant progress has been made in simplifying South Africa's tariff structure and reducing tariff protection, but further progress can be made in removing tariff peaks, reducing tariff dispersion, and lowering the anti-export bias arising from protection. Further, although protection has fallen, the decline has been no faster than in other lower-middle-income economies. The paper also finds that estimates of the level of nominal and effective protection, and their rate of change, are sensitive to the choice of tariff measure (collection duties or scheduled tariff rates) and Input-Output or Supply-Use table, but that the sectoral structure of protection is largely unaffected.

\section{INTRODUCTION}

In a controversial paper during the early 1990s, Trevor Bell (1992) asked the question "Should South Africa further liberalise its trade?" The democratically elected government answered this in the affirmative and agreed to a comprehensive reform of the tariff regime as reflected in its formal Offer to the WTO in $1995 .{ }^{1}$

However, the overall impact of these reforms on the level of protection is subject to a lively academic debate, much of which is taking place within the South African Journal of Economics. Fedderke and Vase (2001: 447) (FV henceforth), for example, argue that "... the much-hyped liberalisation of the South African economy in the 1990s has not been fully realized. ... more of South Africa's output is protected by tariffs in 1998 than in 1988". In response to this, Rangasamy and Harmse (2003:721) (RH henceforth) re-evaluate the data of FV as well introduce new data and conclude that "... to argue that more of South Africa's output has been subjected to increased levels of protection during the 1990s is not only incorrect but is also a misrepresentation of facts" (Rangasamy and Harmse, 2003: 721). Similar sentiments on the extent of liberalisation are expressed by some businesses and labour representatives who have argued that industry "... has been cruelly lashed by the harsh winds of competition introduced through trade liberalisation - specifically lowering of tariffs" (Seboni, 2005). No consensus has been reached and the question remains: "Has South Africa liberalised its trade?"

One of the reasons for the lack of consensus has been the unavailability of detailed tariff data for each year during the 1990s. This paper assembles a consistent set of tariff data at the Harmonised System (HS) 8-digit level for the period 1988-2004 and uses this data to evaluate the extent of liberalisation in South African industries during this time. The paper also extends the work of FV and RH by analysing the sensitivity of measures of protection, particularly effective protection, to the choice of tariff measure, production structure and non-tariff barriers in agriculture. Finally,

* Senior Lecturer at the School of Economics, University of Cape Town. This paper draws upon a more extensive paper prepared for the Trade and Poverty Project, funded by the UK Department for International Development.

${ }^{1}$ See Bell (1997) for an analysis of why the democratically elected government in 1994 pursued an open trade policy.

(C) 2005 Economic Society of South Africa. Published by Blackwell Publishing, 9600 Garsington Road, Oxford OX4 DQ, UK and 350 Main Street, Malden, MA 02148, USA on behalf of ESSA. 
liberalisation in South Africa is benchmarked against a range of countries and regions.

The paper finds that significant progress has been made in simplifying the tariff schedules and reducing tariff protection, but further progress can be made in removing tariff peaks, reducing tariff dispersion, and lowering the anti-export bias arising from protection. Further, although protection has fallen, the decline has been no faster than in other lower-middle-income economies. The paper also finds that estimates of the level of effective and nominal protection, and their rate of change, are lower when using collection duties compared to scheduled tariff rates, but the structure of protection across sectors is similar.

The structure of the paper is as follows. Section 2 presents a brief overview of trade liberalisation in South Africa. Section 3 critiques existing empirical estimates of protection in South African industries. Section 4 discusses the data used in the study and sections 5, 6 and 7 present the results of the data analysis. Section 8 concludes the paper.

\section{A BRIEF HISTORY OF TRADE LIBERALIZATION IN SOUTH AFRICA}

The primary focus of this paper is trade reform during the 1990s. Liberalisation of South Africa's trade regime prior to the 1990s is well documented and the reader is referred to Holden (1992), Bell (1992, 1997), Belli et al. (1993), GATT (1993), Jenkins et al. (1997) and WTO (1998, 2003) for further information. A chronology of various reforms from the early 1970 s is also presented in Table 1.

The first significant shifts away from South Africa's early import substitution industrialisation trade regime, that characterised its early industrial development, began in the 1970s with the relaxation of Quantitative Restrictions (QRs) and the introduction of an export incentive scheme. This process of gradual reform continued into the early 1980s, but was offset by the imposition of surcharges from 1985 in response to the debt crisis, and the increased number of applications by businesses for protection in the form of ad valorem and formula duties during the economic downturn in the late 1980s (Bell, 1992). As a consequence, the tariff regime in the early 1990s remained highly complex. Belli et al. (1993) show that by the end of the 1980s South Africa had the most tariff rates, the widest range of tariffs and the second highest level of tariff dispersion compared to a range of developing countries.

The shift towards a more export oriented trade regime continued in the 1990s with the introduction in 1990 of export subsidies under the General Export Incentive Scheme (GEIS) and the gradual removal of surcharges and the remaining quantitative restrictions (QRs). ${ }^{2}$ The focus of trade reform then shifted to import liberalisation through tariff reductions. This process was spurred by South Africa's commitment in the GATT Uruguay Round to bind $98 \%$ of all tariff lines, reduce the number of tariff rates to six, rationalise the over 12000 tariff lines and replace quantitative restrictions on agricultural products with tariffs. Export subsidies, which were incompatible with WTO rules, were also phased out and finally terminated in 1997.

In addition to multi-lateral liberalisation, the government has also engaged in a number of bilateral trade agreements culminating in the signing of the Southern African Development Community (SADC) Free Trade Protocol in 1996 and the

${ }^{2}$ QRs on agricultural products were still prevalent. 
implementation of the South Africa-European Union Trade, Development and Cooperation Agreement (TDCA) in 2000. Recently, discussions on trade agreements have also commenced with MERCOSUR, India and the United States.

Table 1. Chronology of trade liberalisation from the early 1970 s

\begin{tabular}{|c|c|}
\hline $1972-1976$ & $\begin{array}{l}\text { Export Development Assistance scheme introduced. } \\
\text { Substitution of tariffs for QRs resulting in net decline in protection (Bell, 1997). } \\
\text { Rise in gold price resulting in the appreciation of rand. }\end{array}$ \\
\hline 1980 & Reinforced system of export incentives. \\
\hline $1983-85$ & $\begin{array}{l}\text { Proportion of value of imports subject to QRs fell from } 77 \% \text { to } 23 \% \text { over period. } \\
\text { Relaxation of import permits by switching from a positive list to a negative list. } \\
\text { Real depreciation of rand. }\end{array}$ \\
\hline $1985-1992$ & Proportion of tariff items subject to QRs fell from $28 \%$ in 1985 to less than $15 \%$ in 1992. \\
\hline September 1985 & Introduction of $10 \%$ import surcharge on all imported goods not bound by GATT. \\
\hline August 1988 & $\begin{array}{l}\text { Differential surcharge rates applied to Luxury goods }(60 \%) \text {, Capital goods }(10 \%) \text {, Motor vehicles }(20 \%) \text { and } \\
\text { Intermediate goods }(10 \%) \text {. }\end{array}$ \\
\hline 1989 & $\begin{array}{l}\text { "Structural adjustment programmes" involving a system of duty free imports for exports implemented for motor } \\
\text { vehicles and textiles and clothing. }\end{array}$ \\
\hline 1990 & $\begin{array}{l}\text { - General Export Incentive Scheme (GEIS) introduced. Provided a tax free financial export subsidy to } \\
\text { exporters based on the value of exports, degree of processing and local content of the exported product. }\end{array}$ \\
\hline $1990-91$ & $\begin{array}{l}\text { Reduction of import surcharges to } 40 \%, 5 \%, 15 \% \text { and } 5 \% \text { for Luxury, Capital, Motor vehicles and Intermediate } \\
\text { goods, respectively. }\end{array}$ \\
\hline $23 / 6 / 1994$ & Import surcharges abolished for Capital and Intermediate goods. \\
\hline $1 / 10 / 1995$ & Remaining import surcharges abolished. \\
\hline 1994 & $\begin{array}{l}\text { SA's GATT offer during Uruguay Round: } \\
\text { (1) bound about } 98 \% \text { of all tariff lines at the Harmonised System (HS) eight-digit level as against } 18 \% \text { before the } \\
\text { round } \\
\text { (2) Reduction in the number of tariff rates to six: } 0 \%, 5 \%, 10 \%, 15 \%, 20 \% \text { and } 30 \% \\
\text { (3) Rationalisation of the over } 12000 \text { tariff lines } \\
\text { (4) Tariffication of QRs on agricultural products } \\
\text { (5) Special provisions (extensions of the adjustment period and raised maximum tariff rates) for textile, clothing } \\
\text { and motor vehicle industries granted. } \\
\text { Decision taken to phase out GEIS. } \\
\text { Adoption of anti-dumping and countervailing duties legislation }\end{array}$ \\
\hline 1995 & Payments under GEIS became taxable, range of eligible products reduced. \\
\hline From 1994-97 & $\begin{array}{l}\text { Deregulation of agricultural marketing and control boards established under the Agricultural Marketing Act of } \\
\text { 1968. Import control on agricultural products removed. }\end{array}$ \\
\hline 1996 & $\begin{array}{l}\text { New Tariff Rationalisation Process (TRP) formulated: Tariff lines and peaks to be reduced, Formula and specific } \\
\text { duties to be converted into ad valorem rates, Imports that have no "suitable substitutes" to be duty free, ad valorem } \\
\text { rates of } 30 \% \text { on final products, } 20 \% \text { on intermediate goods and } 10 \% \text { on primary goods are generally not to be } \\
\text { exceeded. } \\
\text { GEIS limited to manufacturing goods. }\end{array}$ \\
\hline Aug 1996 & Protocol (implemented in September 2000) \\
\hline 1 July 1997 & Termination of export subsidies provided under GEIS. \\
\hline 1 Jan 2000 & Implementation of SA-EU Trade, Development and Cooperation Agreement (TDCA) \\
\hline 2000 & Preferential access to US for some products under African Growth and Opportunity Act (AGOA) \\
\hline 21 October 2002 & $\begin{array}{l}2002 \text { SACU Agreement introduces a new institutional structure; a dispute settlement mechanism; the requirement } \\
\text { to have common policies on industrial development, agriculture, competition, and unfair trade practices; and a } \\
\text { new system regarding the common revenue pool and sharing formula (WTO, 2003: viii) }\end{array}$ \\
\hline December 2004 & Preferential Trade Agreement signed between SACU and MERCOSUR \\
\hline
\end{tabular}

Sources. Bell (1992, 1997), Belli et al. (1993), GATT (1993) and WTO (1998, 2003)

\section{CRITIQUE OF EXISTING STUDIES}

As noted in the introduction, the overall impact of tariff reform on the level of protection during the 1990s has been the focus of much debate. The debate between FV (2001, 2004) and RH (2003) centres around the extent to which tariff liberalisation reduced Effective Rates of Protection (ERP) in South African industries. Effective rates of protection measure the protection provided to domestic value added relative to value added in international prices (Greenaway and Milner, 1993), i.e. 
$E R P_{j}=\frac{\left(V_{j}^{*}-V_{j}\right)}{V_{j}}=\frac{t_{j}-\sum_{i} a_{i j} t_{i}}{1-\sum_{i} a_{i j}}$

where $V_{j}^{*}$ is the domestic value added to final product $j$ at tariff distorted prices, $V_{j}$ is the value added under free trade, $t_{j}$ is the tariff on outputs, $t_{i}$ is the tariff on inputs and $a_{i j}$ is the quantity of intermediate input $i$ used in the production of one unit of $j$. ERP therefore increase with a rise in output tariffs, a decline in intermediate good tariffs and a rise in the share of intermediate inputs in total production.

Although subject to severe methodological limitations (Holden and Holden, 1975; Holden and Holden, 1978; Greenaway and Milner, 1993; Anderson, 1998; Holden, 2001), ERP are still widely used to evaluate the structure of protection and therefore the potential for resource allocation across sectors (Greenaway and Milner, 2003). Within South Africa the debate remains inconclusive, largely due to a number of methodological differences in the estimates of FV and RH.

Firstly, estimates of nominal and effective rates of protection are influenced by the choice of protection measure. Neither FV (2001) nor RH (2003) account for the effect of non-tariff barriers (NTBs), which were prevalent in many sectors, particularly agriculture, clothing and textiles, prior to the mid 1990s. ${ }^{3}$ The quantity of imports of agricultural products were largely controlled by marketing boards under the Marketing Act of 1937 and 1968 and only marginal tariffs were imposed on imports. This induces two biases into the estimates of ERP. Firstly, ERP are underestimated for sectors in which non-tariff barriers are prevalent (e.g. grain crops). Secondly, ERP are exaggerated in sectors that use intermediate inputs from sectors protected by non-tariff barriers (e.g. meat processing, grain mill products). Including the effects of NTBs on ERP is restricted by the lack of ad valorem equivalents for these sectors. However, simple sensitivity analysis could provide useful insights into the extent of the bias induced by their exclusion.

A related issue is the choice of scheduled tariff rates or collection rates. FV (2001) measure nominal protection using collection rates, calculated by dividing total duties collected on the value of imports by sector. Collection rates underestimate protection as the quantity and therefore value of imports is not independent of the tariff rate. In the extreme, imports may be driven to zero by a prohibitive tariff. Such protection is not accounted for when using collection rates. In addition, collection rates do not account for exemptions, rebates and drawback of duties, which have been particularly prevalent in clothing (Altman, 1994) and motor vehicles. ${ }^{4}$ This also biases collection rates downwards.

In contrast, RH use ERP obtained from IDC (1996) that are calculated using scheduled tariff rates. Scheduled rates are generally a preferred measure of nominal

\footnotetext{
${ }^{3}$ Subsidies can also be incorporated (Greenaway and Milner, 1993: 83), which is of particular relevance to SA in the early 1990s when the General Export Incentive Scheme (GEIS) was operable.

${ }^{4}$ Altman (1994) also notes that duty free credits, offered under the Structural Adjustment Programme for clothing and textiles in 1989, were used to import final goods covered by very high tariffs. Very low duties were thus paid on these highly protected products. RH (2003) also note that there may be a time lapse between the recording of imports and the payment of duties.
} 
protection, but may exaggerate protection if significant smuggling occurs and rebates are granted. The extent of rebates and smuggling needs to be sufficient such that the suppliers do not price up to the import parity price. The main problem with the $\mathrm{RH}$ study is that they do not use applied tariff rates for 1999. Protection for 1999 is estimated by the IDC (1996) using the tariff phase-down offered to the WTO. As noted by Bell (1997:76), tariff reductions exceeded those required by the commitments entered into by South Africa in the Uruguay round, even in the case of "sensitive" industries such as textiles and clothing, and motor vehicles. It is therefore difficult to draw many conclusions on the extent to which protection has fallen during the 1990s on the basis of the estimates used by $\mathrm{RH}$, although the direction of the change is probably correct.

A further shortcoming in both FV and $\mathrm{RH}$ is that they do not account for protection offered by surcharges that have been implemented at various stages from the 1970s, largely in response to balance of payments pressures. ${ }^{5}$ Surcharges have a marked effect on the level of protection, as is shown in Fig. 1 which measures the ratio of duty collected (including and excluding surcharges) to merchandise imports. The inclusion of surcharges close to doubles protection as measured using collection rates in the early 1990s. Therefore, by not accounting for the removal of surcharges, FV and RH severely underestimate the decline in protection during the 1990s.

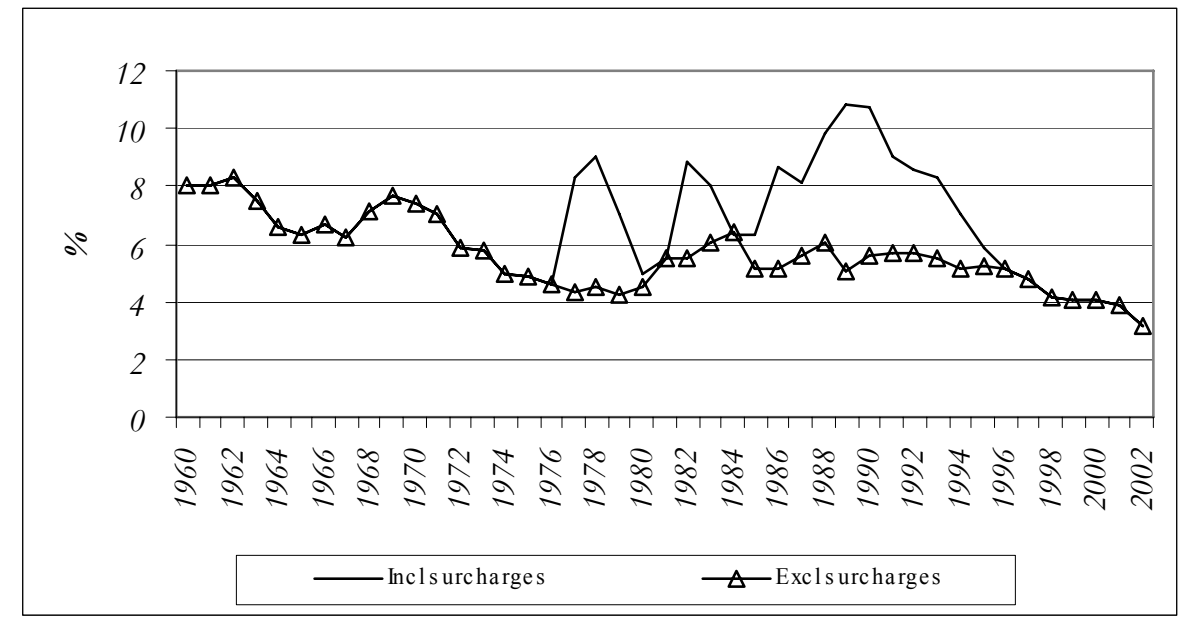

Figure 1. Ratio of duty collected to merchandise imports

Source: Own calculations using Reserve Bank data (Reserve Bank, various years).

A second major concern with the empirical analyses of FV and RH is that their estimates of ERP are based on outdated input-output tables. Both estimates are calculated using the 1993 Input-Output (IO) table provided by Statistics South Africa (1995). The 1993 IO table is a RAS updated version of the 1988 IO table. Essentially, their estimates are therefore based on a technology coefficient matrix for 1988. The RAS updating technique is also known to induce random distortions into the technology coefficient matrix (Parikh, 1979). The use of a single IO table induces

${ }^{5}$ Surcharges were first used in April 1977 to 1979 in response to the cessation of capital inflows after the Soweto riots in 1976. They were reintroduced in the 1980s in response to the debt crisis. 
further biases in the estimates of ERP for other years as substitution effects in intermediate input usage in response to relative price changes are not accounted for. The direction and extent of these biases are indeterminate, making comparisons of ERP across years, sectors and different studies difficult.

There are a number of other minor methodological criticisms of the studies by FV and RH. FV find zero or positive ERP on many of the services industries (medical, dental, health \& other health \& veterinary services, wholesale \& retail trade, electricity, gas \& steam, transport \& storage). It is not clear how these estimates were obtained. According to the Balassa (1965) method used by FV, non-traded goods like services are treated as if they were traded inputs with an infinitely elastic supply. A zero tariff on services is therefore imposed, implying that protection on traded intermediate inputs used by these sectors, as is the case in South Africa, necessarily leads to a negative ERP. ${ }^{6}$ The negative protection rates on the services industry are clearly shown in the ERP estimates for 2000 by van Seventer (2001).

An important source of the disagreement between $\mathrm{FV}$ and $\mathrm{RH}$ is differences in the measurement of changes in protection and the classification of the extent of liberalisation. FV (2001) use an absolute measure of the change in protection (e.g. a reduction in ERP from $10 \%$ to $2 \%$ represents a decline of $8 \%$ percentage points) while $\mathrm{RH}$ propose a proportional measure (e.g. an $80 \%$ decline). Both these approaches are problematic.

Firstly, the proportionate change is a poor proxy for the change in value added arising from liberalisation. This is most clearly reflected in the RH results for other electrical apparatus \& supplies and other food products (Table 5 in their study) which both experience a 93\% reduction in ERP. However, the decline in protection in the former sector $(142 \%$ to $10 \%)$ compared to the latter sector $(30 \%$ to $2 \%$ ) has a larger impact on value added and therefore on production and factor returns. While the absolute measure used by FV captures the size effect in this case, in other cases the proportionate measure is superior. For example, using the absolute approach a decline from $1000 \%$ to $950 \%$ is evaluated equivalently to a decline in protection from $50 \%$ to $0 \%$. A more appropriate measure of the impact of changes in ERP on value added can be obtained by reformulating equation (1) as

$V_{j}^{*}=V_{j}\left(1+E R P_{j}\right)$.

Differentiating equation (2) and re-arranging, the percentage change in domestic value added for good $j$ is represented as ${ }^{7}$ :

$\frac{d V_{j}^{*}}{V_{j}^{\prime}}=\frac{d V_{j}}{V_{j}}+\frac{d E R P_{j}}{\left(1+E R P_{j}\right)}$

Changes in domestic value added therefore arise from changes in world value added (assuming common technology across countries) and changes in domestic tariffs that

${ }^{6}$ In an alternative approach, Corden (1966) treats non-traded inputs in a similar manner to primary factors.

${ }^{7}$ If we assume discrete changes then $\frac{\Delta V^{*}}{V_{0}^{*}}=\frac{\Delta V}{V_{0}} \frac{\left(1+E R P_{1}\right)}{\left(1+E R P_{0}\right)}+\frac{\Delta E R P}{\left(1+E R P_{0}\right)}$ where subscript 0 and 1 refer to first and second period, respectively. 
affect ERP. Using equation (3) and the results of $\mathrm{RH}$, the changes in value added in other electrical apparatus \& supplies and other food products is estimated at $55 \%$ and $21 \%$, respectively.

A second problem is that FV interpret an increase in the ERP from a negative to a less negative value as an increase in protection, and hence include finance $\&$ insurance and other mining into the "More protected" category. While the reduction in tariffs in these sectors did increase value added (see equation 3), this is not equivalent to an increase in protection. Rather, the increase reflects a reduction in tariff-induced distortions in the economy; hence the change is a positive outcome of the liberalisation process.

Their inclusion of sectors such as gold \& uranium or mining and agriculture, forestry and fishing into the "More protected" category is also problematic. No account is taken of the removal of import restrictions on agricultural products during the early 1990s. The rise in protection reflects the tariffication of these non-tariff barriers and not necessarily an increase in actual protection. Gold production is almost entirely produced for the export market and the effective price received by producers equals the world price and not the tariff distorted domestic price. The inclusion of these sectors in the "Most protected" category lies behind FV's (2001: 447) finding that "... more of South Africa's output is protected by tariffs in 1998 than in 1988".

Given these limitations, no definitive conclusion with respect to liberalisation during the 1990s can be drawn. In the following sections new data (collection duties and scheduled tariff rates) are introduced and nominal and effective rates of protection during the 1990s are re-calculated. The sensitivity of estimates of protection to changes in nominal tariff rates (collection data and scheduled rates) and the choice of SupplyUse or Input-Output table are also analysed.

\section{DATA}

For the purpose of this study a coherent set of industry level tariff rates was constructed for the period 1988 to 2004. In constructing this data set, numerous problems needed to be dealt with.

Firstly, the estimation of protection levels at an industry level is made complex by the various types of customs duties used by the South African authorities. The types of customs duties include ad valorem, specific, mixed, compound and formula duties as well as their combinations. ${ }^{8}$ Up to the late 1990 s formula duties and mixed duties were often used to set a lower bound free-on-board (f.o.b.) price for imported products and were particularly prevalent within the clothing and textile sectors. As a result, the ad valorem equivalent of these tariffs could be extremely high. For example, the IDC (1990) estimated ad valorem equivalent tariff rates in 1990 in excess of $1000 \%$ for some

8 Three types of mixed duties are applied, for example: (a) $25 \%$ or $70 \mathrm{c} / \mathrm{kg}$, (b) $325 \mathrm{c} / \mathrm{kg}$ with a maximum of $39 \%$ and (c) $22 \%$ or $27 \%$ with a maximum of $2880 \mathrm{c} / \mathrm{kg}$. In applying the mixed tariff, the higher of the two rates are applied. Formula duties were designed to combat "disruptive competition", but have been phased out as South Africa has adopted an antidumping framework (WTO, 1998: 39). An example of a formula duty is: $10 \%$ or $255 \mathrm{c} / \mathrm{kg}$ less $90 \%$. In this example, if the f.o.b. import price falls below $255 \mathrm{c} / \mathrm{kg}$, additional duties are levied to raise the effective import price to this value. The ad valorem equivalent of the formula duty converges on infinity as the f.o.b. price converges on zero. 
products at the Harmonised System (HS) 8-digit level.

A second problem associated with calculating protection rates is the prevalence of quantitative restrictions during the early 1990s, particularly within the agriculture, food, beverages, tobacco, clothing and rubber sectors (GATT, 1993:77). Although tariffs rates, usually specific tariffs, were applied to these products, these were primarily to generate revenue once an import quota had been granted. ${ }^{9}$ Failure to account for protection through non-tariff barriers will lead to an underestimate of protection, particularly prior to the mid 1990s.

Finally, estimated protection levels vary enormously depending on whether scheduled tariff rates, collection duties and surcharges are used.

Given the complexity of measuring protection within South Africa from the late 1980s, two estimates of nominal protection are used in this study. Firstly, protection is measured using scheduled tariff rates at the HS8-digit level. Secondly, protection is measured using collection duties at the HS6-digit level and is calculated by dividing customs revenue by the import value. Both the scheduled tariff and collection duty rates are adjusted to include surcharges calculated at the HS8-digit level using surcharge revenue obtained from Quantech (2004).

The scheduled tariff rates are obtained from the Trade Analysis and Information System database (TRAINS), the Economic Research Division of the Industrial Development Corporation (IDC) and the Trade and Industrial Policy Strategies (TIPS). Missing years are updated using South African Government Gazettes. Customs revenue data at the HS8-digit level is obtained from Customs \& Excise (obtained from TIPS) and the FV study. A concordance file obtained from TIPS is used to calculate the simple average tariff rates according to the Standard Industrial Classification (SIC) system used in this analysis. ${ }^{10}$

Because of the prevalence of non-ad valorem tariffs, it was important to include some estimate of the protection afforded by these tariff rates. The calculation of ad valorem equivalents for non-ad valorem duties requires f.o.b. prices for the products, often at the HS8-digit level. Although it is possible to use cost-insurance-freight (c.i.f.) prices, which can be calculated by dividing import values by import volumes, these are highly variable, even at the HS8-digit level (Jansen and Joubert, 1998). As an alternative, formula and mixed duties are replaced by collection rates if the latter exceeded the ad valorem component of the scheduled rates. This process underestimates protection levels as highly protected products may not be imported and exemptions on duty are frequently granted. It was not possible to estimate the ad valorem equivalent of nontariff barriers, which were prevalent in some sectors prior to 1994. However, coverage of import controls tended to apply to products already liable to high tariffs, with the exception of agriculture (GATT, 1993: 77). Moreover the sectors in which import licensing was eliminated were also those experiencing large reductions in tariffs

${ }^{9}$ It is also argued that import duties in the motor vehicle industry acted as fiscal, rather than protective, measures during the early 1990s since the local content programme prevented foreign competition for assembled vehicles (GATT, 1993: 162).

10 The simple average tariffs tend to bias estimated protection upwards as most information is available for highly protected products. Import weighted averages could be used, but these are biased downwards as consumers substitute highly protected products for less-protected products. 
(Jonsson and Subramanian, 2000). The reduction in tariffs may therefore serve as a reasonable proxy for the decline in protection within these sectors.

\section{NOMINAL PROTECTION}

Table 2 presents detailed information on the SACU tariff structure between 1990 and 2004. Substantial progress has been made in simplifying the tariff structure of the early 1990s. The total number of HS8-digit tariff lines fell from over 11200 in 1994 to under 7000 in 2004. The tariff structure has also been simplified with the number of HS8digit lines bearing formula, mixed or specific duties declining from 3524 in 1994 (30\% of total) to 205 in 2004 ( $3 \%$ of total), although almost half of this reduction took place between 2003 and 2004. The strongest reductions took place in clothing and textiles where the percentage of lines under ad valorem tariffs rose from under 30\% in 1994 to $100 \%$ in 2004. Non-ad valorem tariffs are still imposed on some food, beverages, tobacco and coke $\&$ petroleum products (see Table 3).

While the number of tariff lines has fallen, there is still scope for further simplification of the tariff structure. The number of ad valorem tariff bands remains high (38 in 2004 for Most Favoured Nation (MFN) countries) and still exceeds the 6 tariff rates proposed in South Africa's GATT/WTO Uruguay Round offer. If non-ad valorem tariff bands are included, the number of different rates in 2004 rises to $100 .{ }^{11}$ Approximately $1.2 \%$ of MFN tariff lines in 2004 are still subject to nuisance tariffs (tariff level exceeds zero, but is less than or equal to $2 \%$ ) and could be reduced to zero with little impact. Tariff dispersion, as reflected in the coefficient of variation, also remains relatively high (1.4 for MFN duties in 2004). The dispersion of tariffs is also shown in the increased percentage of domestic "spikes" (tariff $>3$ times the economy wide average) in total tariff lines from $3.7 \%$ in 1994 to over $8.5 \%$ in 2004 . Finally, the signal for domestic resource allocation has been diluted by the implementation of the various trade agreements (SA-EU TDCA and SADC Free Trade Protocol) which has resulted in separate $\mathrm{MFN}, \mathrm{EU}$ and SADC duties.

To evaluate the change in nominal protection during the 1990s, Table 3 presents the simple average scheduled tariff rates and collection rates for 1994, 1998 and 2003/4. The averages are presented for the 1-digit SIC groupings (manufacturing, agriculture and mining) as well as for 32 industrial sectors. ${ }^{12}$ The rates for 1994 include the average surcharge rate which is presented in column 1. Fig. 2 presents the simple average nominal protection rate, inclusive of surcharges, over the period 1990-2004.

A comparison of the scheduled rates and the collection rates in Table 3 and Fig. 2 reveals the downward bias in the level and decline in protection when using the latter. Collection rates are on average 40\% lower than the scheduled rates in 1994, but this difference declines to less than $5 \%$ in $2003 / 4 .{ }^{13}$ In both cases overall protection fell from 1993. According to the scheduled rates, the simple average tariff rate, inclusive of surcharges, fell from $22 \%$ in 1994 to $7.9 \%$ in 2004. Protection according to collection rates declined from $13.6 \%$ to $6.1 \%$, with most of the decline arising from the removal

11 The number of rates in 1990 and 1994 were 733 and 723, respectively. These numbers are clearly influenced by the method used to calculate ad valorem equivalents.

12 This is the same classification used by FV (2001).

${ }_{13}$ Large biases are evident in wearing apparel, textiles and motor vehicles as a result of the extensive use of rebates and drawbacks. 
of surcharges. Since 2000, most of the decline in average protection has arisen from liberalisation in accordance with the SA-EU Free Trade Agreement and the SADC Free Trade Protocol, with little progress made in reducing MFN tariffs. ${ }^{14}$

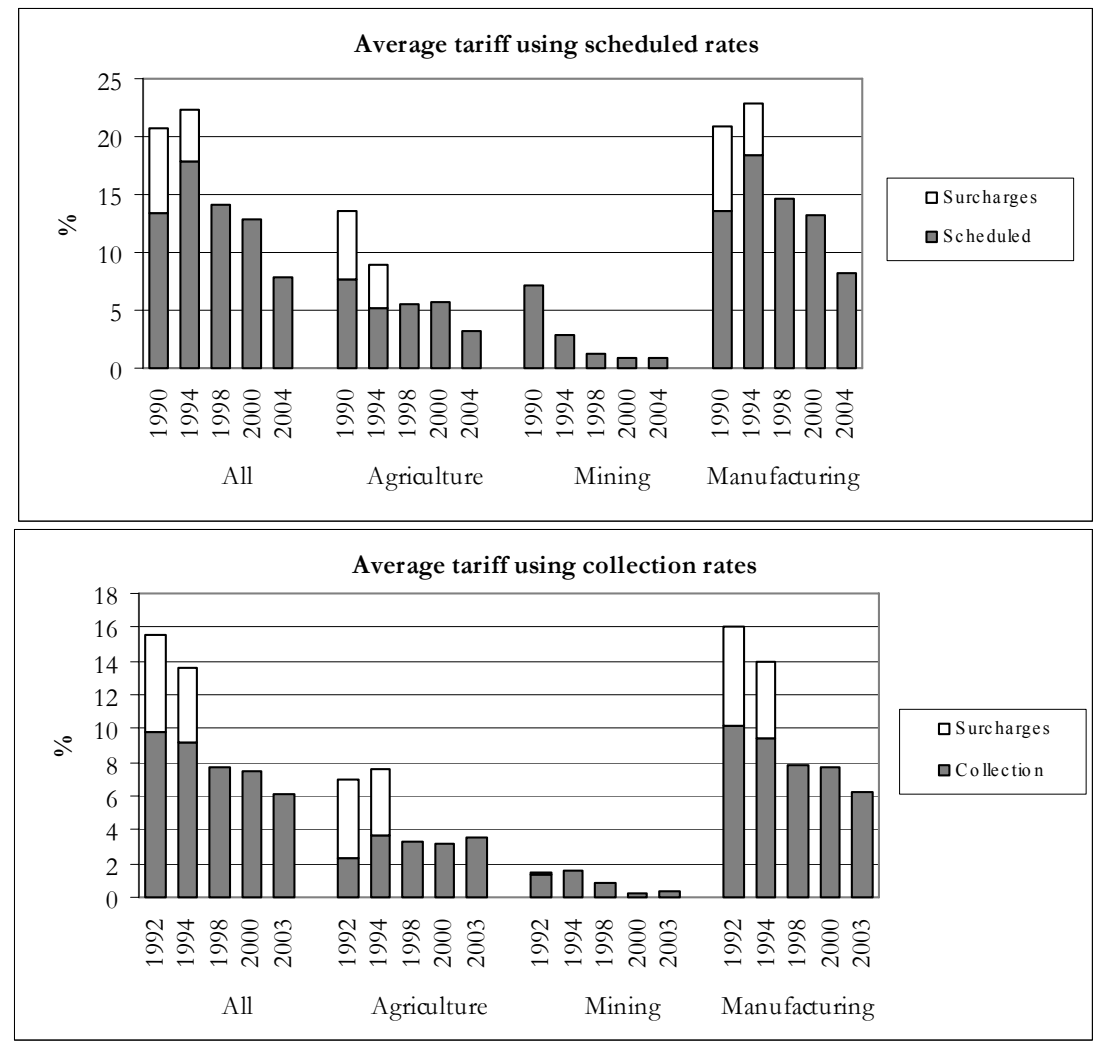

Figure 2. Simple average nominal protection

Turning to the estimates of nominal protection at the sector level, the data reveals wide variations in the level of protection and change thereof across sectors. While estimates of the level of protection are also sensitive to the choice of collection duties or scheduled rates, the sectoral structure of protection and the change in protection are largely unaffected. Simple pairwise correlation coefficients for manufacturing exceed 0.73 in all cases. The Spearman rank correlation coefficients are higher (0.81 for changes in protection and in excess of 0.91 for the level of protection between 1994 and 2004). This suggests that while the results of FV underestimate the decline in protection during the 1990 s, the sectoral bias may be limited.

Average nominal protection fell in all sectors using both scheduled and collection rates, but relatively large declines (over 17\% using scheduled rates) were experienced in

14 Average protection using scheduled rates rose from 1990-93. This reflects the tariffication of non-tariff barriers in food and rising protection within the clothing and textile industry under the revised Structural Adjustment Programme (SAP) in 1992 and 1993. As argued by GATT (1993:170) in the latter case: "The sector represents a clear-cut case of rent-seeking by entrenched special interests, with no final arbiter to guide the industry towards international competitiveness on the basis of free trade". 
beverages, textiles, footwear, wearing apparel and communication equipment. Low declines (less than 6\% using scheduled rates) in protection were experienced in wood products, paper products, basic chemicals and basic iron \& steel sectors. Despite the decline in overall protection, nominal protection using scheduled rates remains high in wearing apparel, tobacco and footwear where average tariffs exceed $20 \%$. Finally, the tariff structure has been simplified significantly, as shown in the increased proportion of HS8-digit tariff lines under ad valorem duties for all sectors.

Table 2. Structure of tariffs of SACU, 1990-2004

\begin{tabular}{|c|c|c|c|c|c|c|c|c|c|}
\hline & 1990 & 1994 & 1998 & $\begin{array}{l}2002 \\
\text { MFN } \\
\end{array}$ & $\begin{array}{l}2002 \\
\text { EU } \\
\end{array}$ & $\begin{array}{l}2002 \\
\text { SADC }\end{array}$ & $\begin{array}{l}2004 \\
\text { MFN } \\
\end{array}$ & $\begin{array}{l}2004 \\
\text { EU }\end{array}$ & $\begin{array}{l}2004 \\
\text { SADC } \\
\end{array}$ \\
\hline 1. Number of tariff lines & 12475 & 11231 & 7773 & 7919 & 7919 & 7919 & 6697 & 6697 & 6697 \\
\hline ad valorem & 8649 & 7707 & 5793 & 5916 & 7637 & 7862 & 6492 & 6504 & 6658 \\
\hline Specific & 499 & 398 & 214 & 194 & 201 & 55 & 135 & 135 & 37 \\
\hline Mixed & 566 & 2071 & 1736 & 1802 & 77 & 2 & 64 & 53 & 2 \\
\hline Formula & 2695 & 1004 & 24 & 5 & 3 & 0 & 5 & 5 & 0 \\
\hline Compound & 66 & 51 & 6 & 2 & 1 & 0 & 1 & 0 & 0 \\
\hline \multicolumn{10}{|l|}{ 2. Tariff distribution by type of duty $(\%)$} \\
\hline ad valorem & 69 & 69 & 75 & 75 & 96 & 99 & 97 & 97 & 99 \\
\hline Specific & 4 & 4 & 3 & 2 & 3 & 1 & 2 & 2 & 1 \\
\hline Mixed & 5 & 18 & 22 & 23 & 1 & 0 & 1 & 1 & 0 \\
\hline Formula & 22 & 9 & 0 & 0 & 0 & 0 & 0 & 0 & 0 \\
\hline Compound & 1 & 0 & 0 & 0 & 0 & 0 & 0 & 0 & 0 \\
\hline 3. Number of tariff bands & 733 & 723 & 275 & & & & 100 & 101 & 43 \\
\hline ad valorem & 38 & 37 & 45 & & & & 38 & 54 & 25 \\
\hline Other & 695 & 686 & 230 & & & & 62 & 47 & 18 \\
\hline 4. Duty-free tariff lines ( $\%$ all lines) & 24 & 26 & 42 & 44 & 45 & 65 & 53 & 56 & 81 \\
\hline 5. Domestic tariff "spikes" ( $\%$ all lines)a & 0.7 & 3.7 & 4.5 & 4.6 & 6.4 & 8.7 & 8.9 & 8.5 & 14.9 \\
\hline 6. International tariff "spikes" ( $\%$ all lines) ${ }^{\mathrm{b}}$ & 43.7 & 43.5 & 39.4 & 35.1 & 33.3 & 8.7 & 21.2 & 20.1 & 5.8 \\
\hline 7. Coefficient of variation ${ }^{c}$ & 0.9 & 1.1 & 1.2 & 1.1 & 1.1 & 1.5 & 1.4 & 1.4 & 2.4 \\
\hline 8. "Nuisance" applied rates ( $\%$ all lines) ${ }^{\mathrm{d}}$ & 2.2 & 1.5 & 1.9 & 1.5 & 1.4 & 0.1 & 1.2 & 1.8 & 0.1 \\
\hline
\end{tabular}

Notes: Calculations based on tariff schedules including ad valorem equivalents.

a. Domestic tariff spikes are defined as those exceeding three times the overall simple average applied rate.

b. International tariff spikes are defined as those exceeding $15 \%$.

c. Coefficient of variation is calculated as the standard deviation divided by the overall average.

d. Nuisance rates are those greater than zero, but less than or equal to $2 \%$.

\section{EFFECTIVE PROTECTION AND ANTI-EXPORT BIAS}

While nominal tariffs reflect protection on final output, they are an imperfect proxy for protection on value added. For example, value added within a sector may become more protected if protection on intermediate inputs declines relatively rapidly compared to protection on its output. To assess the impact of trade liberalisation during the 1990s on value added, this section presents estimates of effective protection using equation (1). Calculations of value added in international prices and the production coefficients $\left(a_{i j}\right)$ take into account exports that are sold abroad at international prices. The Balassa (1965) approach is followed and non-traded products are given a zero tariff rate. 


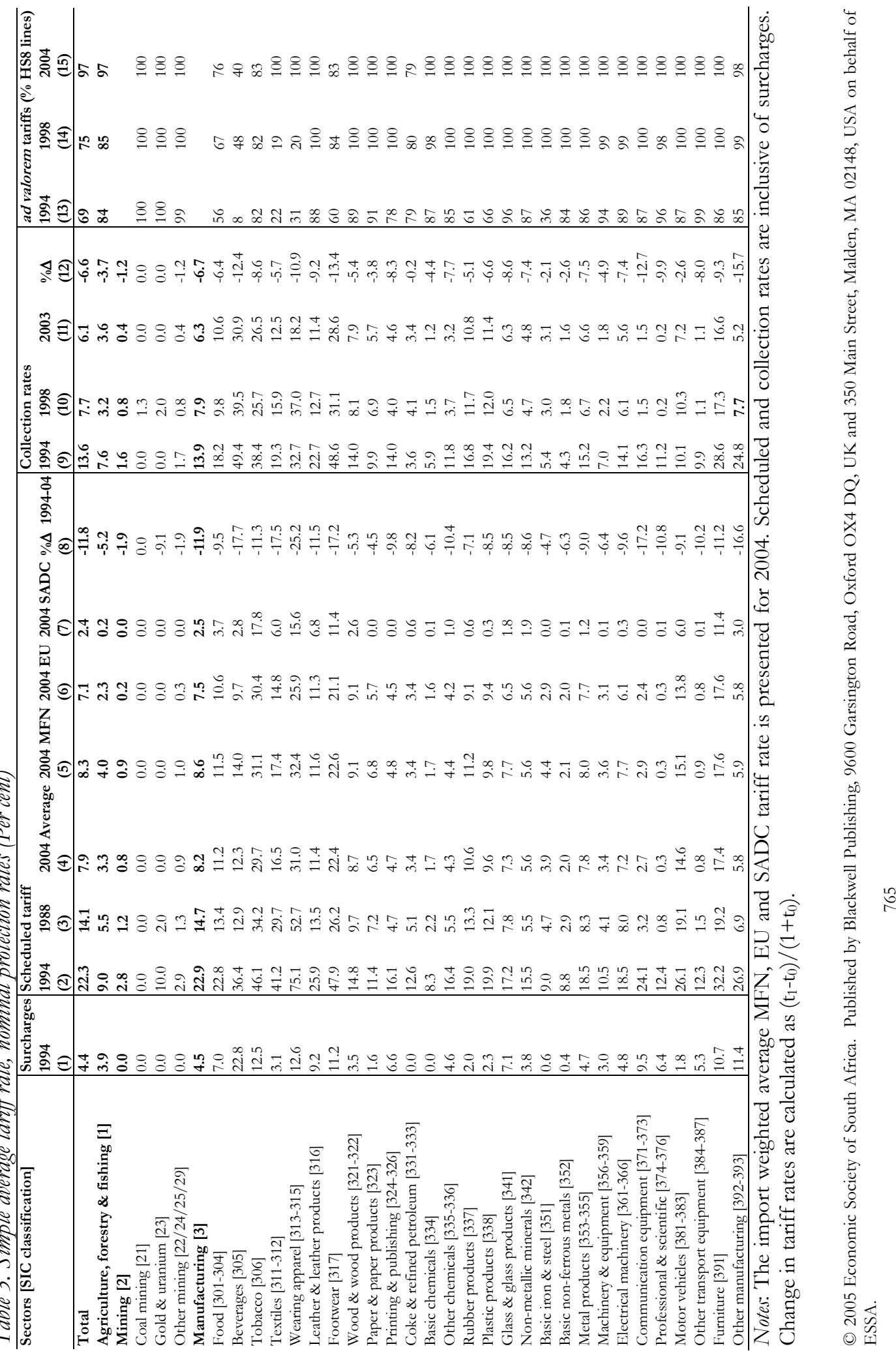




\section{(a) Sensitivity of ERP to Input-output or Supply-use tables}

As discussed a severe shortcoming of the FV and RH studies is that their estimates of ERP are based on a single outdated input-output table for 1993 and may therefore be biased. To test the sensitivity of estimated ERP to choice of intermediate input structure, ERP are calculated for the period 1988 to 2004 using Input-Output (IO) tables for 1988, 1989 and 1993 and Supply-Use (SU) tables for 1993, 1998, 1999 and 2000 (CSS, 1993, 1995; SSA, 1995, 1999, 2001, 2002, 2003). ${ }^{15}$

The sector classification of the IO and SU tables are based on the $4^{\text {th }}$ and $5^{\text {th }}$ editions of the SIC system and are therefore not directly comparable. To facilitate comparability, these tables were reduced to 43 industrial sectors that are roughly consistent with the classification presented in Table 3. ${ }^{16}$ Fig. 3 compares the weighted average ERP for manufacturing between the period 1988 to 2004 using the various IO and SU tables. The estimates are based on the scheduled tariff rates.

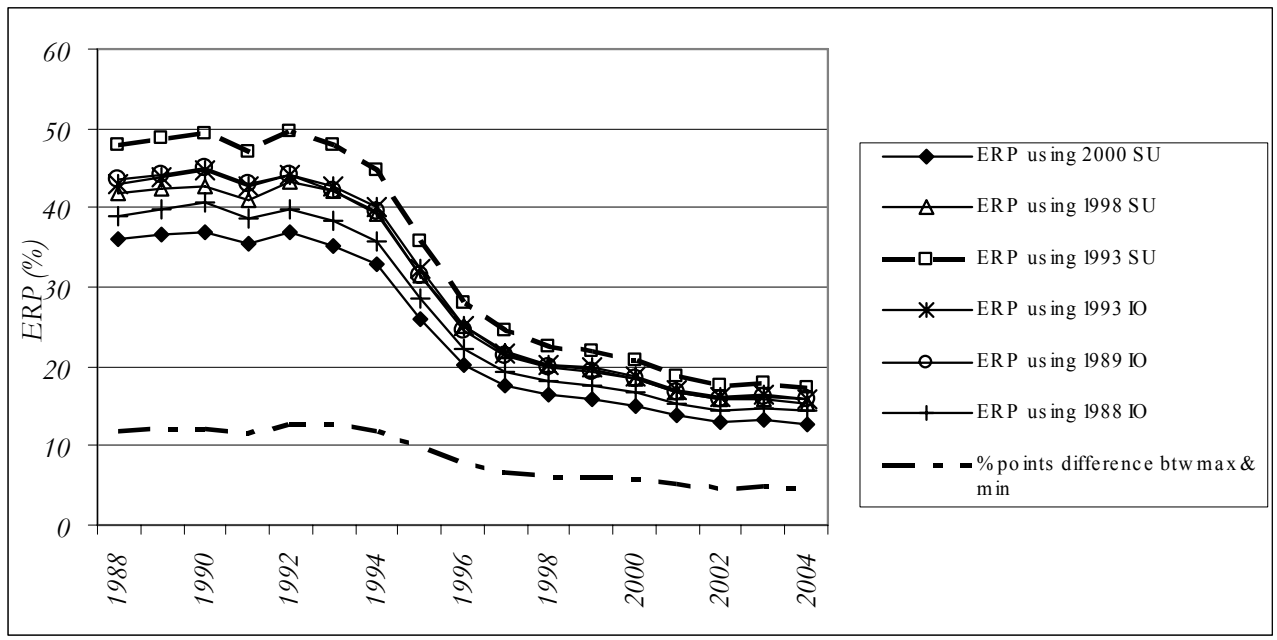

Figure 3. Sensitivity of ERP in manufacturing to choice of Input-output or Supply-use table Note: The sum of imports from 1993-2004 are used as weights.

As is shown in Fig. 3, estimates of ERP are very sensitive to the selection of IO or SU table. The estimated ERP are bounded at the top by the results using the $1993 \mathrm{SU}$ table and at the bottom by the results from the $2000 \mathrm{SU}$ table. The difference between the maximum and minimum averages 12 percentage points until the mid 1990s, but then falls to 4.6 percentage points in 2004.

However, the choice of IO or SU table has little effect on the structure of ERP across sectors. Cross sector correlation coefficients exceed 0.8 in all cases. Similarly, the sectoral growth rates of ERP between 1993 and 2004 (calculated using equation 3) are very similar irrespective of the choice of IO or SU table. The correlation

15 The IO table for 1988 is based on raw data, while the other IO tables are RAS updates. The SU tables for 1993 and 2000 are calculated using survey data, while the remainder are RAS updates of the 1993 SU table.

16 Some minor differences between the reduced IO and SU tables remain. The SU tables include a sector for government and a sector for Professional \& scientific equipment. The latter is included in Other manufacturing. 
coefficients using growth rates exceed 0.97 in all cases. These results are robust to the choice of scheduled tariff rates or collection duties.

In conclusion, the choice of $\mathrm{IO}$ or $\mathrm{SU}$ tables affects estimates of the level of effective protection, but has a marginal impact on the sectoral structure of protection and the change in protection over time.

\section{(b) Changes in ERP by sector}

To compare changes in ERP over time, a table of ERP is constructed drawing on all the available IO and SU tables. The ERP values for 1988 and 1989 are drawn from 1988 and 1989 IO tables, respectively. The ERP values 1993, 1998, 1999 and 2000 are drawn from their respective SU tables. The interim years are calculated as a weighted average using the estimated ERP of the two tables that bound the period. ${ }^{17}$ Table 4 presents the relevant values for 1993, 2000 and 2004 using scheduled and collection rates. Estimates of effective protection excluding surcharges are also presented for 1993.

These results suggest that trade liberalisation has substantially reduced effective protection of South African industries during the 1990s, but the extent of the decline is dependent on the measure of nominal protection used. The average ERP in manufacturing fell from 48\% in 1993 to $12.7 \%$ in 2004 according to the scheduled rates (inclusive of surcharges) and from 30.8\% to $8 \%$ between 1993 and 2003 according to the collection rates. As found in the analysis of nominal protection, the use of collection rates leads to lower estimates of the level and decline in protection. The inclusion of surcharges also significantly raises estimates of effective protection, as revealed in the comparative results for 1993. Protection also fell in agriculture and mining, but off a lower base. Tariff distortions on services also diminished and the simple average ERP rose from between $-4.5 \%$ and $-5.5 \%$ to approximately $-2 \%$.

In comparison to other SA studies, this study finds both higher average protection rates during the early 1990s and also larger declines in ERP over the 1990s, although much of the difference can be accounted for by the inclusion of surcharges. Tsikata (1999) estimates a decline in ERP in manufacturing from $30.2 \%$ in 1990 to $22.2 \%$ in 1996 (a 6.1\% decline). In contrast, this study estimates that ERP fell from 44\% to 26\% over the same period (a decline of 12.4\%). RH (2003), who use IDC (1996) results, estimate that the simple average ERP in manufacturing fell from 30\% in 1993 to 19\% in 1999 , which is very close to the estimates in this study if surcharges are excluded $(33.7 \%$ to $19.5 \%)$. The inclusion of surcharges raises ERP to $48 \%$ in 1993 . Finally, as found by FV (2001), declines in ERP are relatively modest between 1988 and 1998 if collection rates are used. However, estimates of liberalisation rise once surcharges are included and the period of analysis is extended to 2004. The sectoral structure of ERP estimated in this study also differs significantly from those of FV with very low correlation coefficients in each year. The difference in results reflects the sensitivity of estimates of ERP to the inclusion of surcharges, the use of different IO or SU tables and different approaches to estimating ad valorem equivalents.

17 A linearly declining weight is used, e.g. the value for 1994 is calculated as $\alpha_{94} \mathrm{SU}_{93} 3_{94}+(1-$ $\left.\alpha_{94}\right)_{\text {SU98 }}{ }_{94}$ where $\alpha_{94}=(1998-1994) /(1998-1993)$ and SU93 94 and SU9894 are the ERP for 1994 calculated using the 1993 and 1998 SU tables, respectively. 
Table 4. Effective rates of protection by sector (Per cent)

\begin{tabular}{|c|c|c|c|c|c|c|c|c|c|c|}
\hline \multirow[b]{2}{*}{ Sector [SIC code] } & \multicolumn{5}{|c|}{ Scheduled rates } & \multicolumn{5}{|c|}{ Collection rates } \\
\hline & $\begin{array}{l}1993 \text { excl. } \\
\text { surcharge }\end{array}$ & 1993 & 2000 & 2004 & $\Delta$ ERP 93-04 & $\begin{array}{l}1993 \text { excl. } \\
\text { surcharge }\end{array}$ & 1993 & 2000 & 2003 & $\Delta$ ERP 93-04 \\
\hline Agriculture, forestry, fishing [1] & 2.9 & 10.0 & 5.3 & 1.7 & -7.5 & 1.0 & 8.1 & 2.1 & 3.1 & -4.6 \\
\hline Mining [2] & 2.9 & 2.3 & 0.1 & 0.2 & -2.0 & 0.7 & 0.0 & -0.7 & -0.3 & -0.3 \\
\hline Manufacturing [3] & 33.7 & 48.0 & 15.1 & 12.7 & -23.8 & 17.1 & 30.8 & 9.8 & 8.0 & -17.5 \\
\hline Services [4-9] & -4.2 & -5.5 & -2.4 & -2.2 & 3.6 & -3.1 & -4.5 & -2.0 & -1.9 & 2.8 \\
\hline Agriculture, forestry \& fishing [1] & 2.9 & 10.0 & 5.3 & 1.7 & -7.5 & 1.0 & 8.1 & 2.1 & 3.1 & -4.6 \\
\hline Coal mining [21] & -3.6 & -4.7 & -2.5 & -2.2 & 2.6 & -2.4 & -3.6 & -1.9 & -1.6 & 2.0 \\
\hline Gold and uranium mining [23] & 12.4 & 11.3 & -2.3 & -2.1 & -12.0 & -2.2 & -3.3 & -1.9 & -1.7 & 1.7 \\
\hline Other mining [22/24/25/29] & 3.0 & 2.5 & 0.2 & 0.3 & -2.1 & 0.7 & 0.1 & -0.6 & -0.2 & -0.4 \\
\hline Food [301-304] & 51.8 & 85.5 & 45.7 & 38.4 & -25.4 & 39.8 & 71.3 & 33.2 & 33.7 & -22.0 \\
\hline Beverages [305] & 20.6 & 84.2 & 25.5 & 21.5 & -34.1 & 60.9 & 151.8 & 90.8 & 76.1 & -30.1 \\
\hline Tobacco [306] & 403.7 & 693.4 & 213.4 & 194.8 & -62.8 & 196.7 & 398.6 & 104.9 & 127.2 & -54.4 \\
\hline Textiles [311-312] & 156.8 & 183.3 & 88.2 & 52.3 & -46.3 & 46.7 & 62.2 & 43.2 & 33.7 & -17.6 \\
\hline Wearing apparel [313-315] & 242.2 & 287.7 & 116.3 & 76.6 & -54.4 & 59.2 & 102.1 & 94.2 & 40.3 & -30.6 \\
\hline Leather \& leather products [316] & 36.9 & 60.5 & 18.1 & 17.9 & -26.6 & 36.6 & 60.8 & 23.6 & 20.3 & -25.2 \\
\hline Footwear [317] & 108.3 & 153.0 & 48.0 & 50.0 & -40.7 & 144.6 & 200.4 & 89.6 & 80.7 & -39.9 \\
\hline Wood \& wood products [321-322] & 30.0 & 41.2 & 13.7 & 15.0 & -18.6 & 24.3 & 35.2 & 13.9 & 13.4 & -16.1 \\
\hline Paper \& paper products [323] & 17.5 & 20.4 & 10.9 & 11.2 & -7.6 & 18.3 & 21.1 & 12.4 & 9.9 & -9.3 \\
\hline Printing \& publishing [324-326] & 16.4 & 35.8 & 4.6 & 4.5 & -23.1 & 12.3 & 31.2 & 3.1 & 5.0 & -19.9 \\
\hline Coke \& petroleum [331-333] & 35.0 & 34.6 & 11.8 & 8.4 & -19.5 & 9.7 & 9.5 & 11.5 & 9.0 & -0.4 \\
\hline Basic chemicals [334] & 17.5 & 16.2 & 0.9 & 1.5 & -12.7 & 12.8 & 11.5 & 0.7 & 0.6 & -9.8 \\
\hline Other chemicals [335-336] & 24.3 & 39.2 & 6.8 & 7.2 & -23.0 & 13.0 & 26.6 & 5.3 & 4.4 & -17.5 \\
\hline Rubber products [337] & 38.0 & 49.6 & 34.0 & 29.6 & -13.4 & 43.9 & 56.2 & 30.9 & 31.4 & -15.8 \\
\hline Plastic products [338] & 45.1 & 64.3 & 20.7 & 19.9 & -27.0 & 46.6 & 66.4 & 23.7 & 25.3 & -24.7 \\
\hline Glass \& glass products [341] & 18.5 & 39.4 & 13.8 & 13.4 & -18.6 & 17.6 & 38.5 & 11.7 & 11.5 & -19.6 \\
\hline Non-metallic minerals [342] & 24.3 & 38.0 & 9.9 & 10.9 & -19.7 & 20.5 & 34.0 & 9.3 & 9.6 & -18.2 \\
\hline Basic iron \& steel [351] & 17.8 & 18.5 & 10.4 & 9.2 & -7.9 & 10.7 & 11.5 & 7.5 & 7.5 & -3.6 \\
\hline Basic non-ferrous metals [352] & 14.7 & 15.8 & 3.3 & 2.7 & -11.3 & 7.3 & 8.4 & 2.0 & 2.1 & -5.8 \\
\hline Metal products [353-355] & 33.9 & 60.4 & 16.2 & 16.2 & -27.6 & 29.1 & 55.2 & 13.1 & 13.8 & -26.7 \\
\hline Machinery \& equipment [356-359] & 9.1 & 20.5 & 3.3 & 2.9 & -14.6 & 5.2 & 16.4 & 0.2 & -0.2 & -14.3 \\
\hline Electrical machinery [361-366] & 27.0 & 46.0 & 14.7 & 13.8 & -22.0 & 23.1 & 42.0 & 10.6 & 10.3 & -22.3 \\
\hline Communication equip [371-373] & 29.0 & 57.3 & 1.4 & 0.9 & -35.8 & 9.4 & 33.6 & -0.5 & -0.7 & -25.7 \\
\hline Professional \& scientific [374-376] & -0.7 & 14.6 & -6.6 & -5.8 & -17.8 & 5.6 & 22.2 & -5.4 & -5.1 & -22.3 \\
\hline Motor vehicles [381-383] & 66.1 & 73.8 & 32.8 & 28.7 & -25.9 & 18.7 & 25.2 & 13.9 & 9.3 & -12.7 \\
\hline Other transport equip [384-387] & 8.5 & 18.1 & -3.5 & -2.9 & -17.8 & 5.9 & 15.6 & -2.1 & -1.4 & -14.7 \\
\hline Furniture [391] & 48.0 & 85.1 & 39.4 & 41.1 & -23.8 & 45.1 & 82.6 & 40.9 & 41.2 & -22.7 \\
\hline Other manufacturing [392-393] & 23.4 & 46.2 & 17.5 & 15.7 & -20.9 & 23.8 & 47.0 & 14.9 & 14.2 & -22.3 \\
\hline Electricity [41] & -0.8 & -1.1 & -0.8 & -0.7 & 0.5 & -0.6 & -0.9 & -0.6 & -0.5 & 0.4 \\
\hline Water supply [42] & -1.7 & -2.3 & -1.7 & -1.6 & 0.7 & -1.3 & -1.9 & -1.3 & -1.3 & 0.6 \\
\hline Building construction [51] & -13.6 & -17.1 & -8.3 & -7.9 & 11.1 & -10.5 & -14.6 & -7.0 & -6.9 & 8.9 \\
\hline Civil engineering [52-53] & -13.4 & -16.7 & -5.3 & -5.1 & 13.9 & -10.0 & -13.7 & -4.5 & -4.5 & 10.7 \\
\hline Wholesale \& retail trade [61-63] & -2.1 & -2.8 & -1.2 & -1.1 & 1.7 & -1.6 & -2.3 & -1.1 & -1.0 & 1.4 \\
\hline Catering \& accommodation [64] & -4.8 & -7.9 & -3.2 & -2.6 & 5.7 & -4.8 & -7.7 & -3.6 & -3.3 & 4.8 \\
\hline Transport \& storage [71-74] & -4.9 & -5.6 & -3.1 & -2.5 & 3.2 & -2.7 & -3.5 & -2.4 & -2.0 & 1.5 \\
\hline Communication [75] & -2.3 & -3.2 & -1.4 & -1.2 & 2.1 & -1.4 & -2.4 & -1.1 & -0.9 & 1.5 \\
\hline Finance \& insurance [81-82] & -0.4 & -0.6 & -0.4 & -0.4 & 0.2 & -0.3 & -0.5 & -0.4 & -0.4 & 0.2 \\
\hline Business services [83-88] & -1.4 & -1.9 & -0.6 & -0.5 & 1.4 & -1.0 & -1.5 & -0.5 & -0.4 & 1.1 \\
\hline Medical, dental \& veterinary [93] & -4.7 & -6.3 & -2.3 & -2.0 & 4.6 & -3.2 & -5.0 & -1.8 & -1.6 & 3.6 \\
\hline Other producers [98] & -2.4 & -3.2 & -1.7 & -1.5 & 1.7 & -1.7 & -2.5 & -1.2 & -1.1 & 1.5 \\
\hline General government services [99] & -2.3 & -3.2 & -1.3 & -1.1 & 2.1 & -1.5 & -2.5 & -0.9 & -0.8 & 1.8 \\
\hline
\end{tabular}

Note: The import weighted averages for manufacturing and mining are presented. The simple average ERP for services is presented. Changes in ERP are calculated as $\triangle \mathrm{ERP} /(1+\mathrm{ERP})$ using data inclusive of surcharges. 
Wide variations in the level and decline in protection are also found at the sector level. Protection, inclusive of surcharges, fell between 1993 and 2004 in all sectors, but particularly large declines (more than 35\%) in ERP, calculated using schedule rates, were experienced in tobacco, textiles, wearing apparel, footwear and communication equipment. Despite this, tobacco, textiles, wearing apparel and footwear still remain amongst the top 5 most protected sectors with ERP calculated using schedule rates still exceeding $40 \%$.

The sectors experiencing the greatest declines in ERP based on collection rates are tobacco, leather products, footwear, communication equipment and professional \& scientific equipment. Although these differ slightly from the top 5 using ERP based on scheduled rates, the sectoral pattern of growth in ERP is relatively robust to the choice of scheduled or collection rates. The pairwise correlation coefficient of the change in ERP across sectors is 0.87 and the Spearman rank correlation coefficient is 0.86 . The sectoral structure of protection using ERP and nominal protection is also very similar, although the former are generally higher. For all years, the correlation between nominal and effective protection exceeds 0.8 when using schedule rates and 0.7 when using collection rates for all years. High correlation coefficients are also found by van Seventer (2001).

To facilitate comparison with the results of FV and RH, Table 5 groups sectors according to the extent to which ERP based on schedule rates have changed between 1993 and 2004. The share of GDP in 1993 and 2000 accounted for by these sectors is also presented.

Table 5. Change ERP, 1993-2004, scheduled rates inclusive of surcharges

\begin{tabular}{|c|c|c|c|}
\hline$\Delta \mathrm{ERP} \leq-25 \%$ & $-15 \% \leq \Delta \mathrm{ERP}<-25 \%$ & $0 \leq \Delta \mathrm{ERP}<-15 \%$ & Positive \\
\hline Tobacco [306] & Furniture [391] & Rubber products [337] & Finance \& insurance $[81-82]$ \\
\hline Wearing apparel [313-315] & Printing \& publishing [324-326] & Basic chemicals [334] & Electricity [41] \\
\hline Textiles [311-312] & Other chemicals [335-336] & Gold and uranium mining [23] & Water supply [42] \\
\hline Footwear [317] & Electrical machinery [361-366] & Basic non-ferrous metals [352] & Business services [83-88] \\
\hline Communication equip [371-373] & Other manufacturing [392-393] & Basic iron \& steel [351] & Other producers [98] \\
\hline Beverages [305] & Non-metallic minerals [342] & Paper \& paper products [323] & Wholesale \& retail [61-63] \\
\hline Metal products [353-355] & Coke \& petroleum [331-333] & Agriculture, forestry, fishing [1] & Communication [75] \\
\hline Plastic products [338] & Glass \& glass products [341] & Other mining $[22 / 24 / 25 / 29]$ & General government [99] \\
\hline \multicolumn{3}{|c|}{ Leather \& leather products [316] Wood products [321-322] } & Coal mining [21] \\
\hline Motor vehicles [381-383] & Professional \& scientific [374-376] & & Transport \& storage [71-74] \\
\hline \multirow[t]{4}{*}{ Food [301-304] } & Other transport equip [384-387] & & Medical, dental, veterinary [93] \\
\hline & Machinery \& equip [356-359] & & Catering \& accommodation [64] \\
\hline & & & Building construction [51] \\
\hline & & & Civil engineering [52-53] \\
\hline \multicolumn{4}{|l|}{ Share 1993 GDP } \\
\hline $8.8 \%$ & $8.6 \%$ & $14.3 \%$ & $68.3 \%$ \\
\hline \multicolumn{4}{|l|}{ Share 2000 GDP } \\
\hline $7.6 \%$ & $6.6 \%$ & $13.1 \%$ & $72.7 \%$ \\
\hline
\end{tabular}

As is revealed in Table 5, the sectors in which ERP fell by more than $25 \%$ accounted for $7.6 \%$ of GDP using 2000 values. Sectors in the intermediate range $(-15 \% \leq \Delta \mathrm{ERP}$ $<-25 \%)$ and the low range $(0 \leq \Delta \mathrm{ERP}<-15 \%)$ accounted for $6.6 \%$ and $13.1 \%$ of 
GDP using 2000 values, respectively. By far the largest grouping in terms of GDP share is the category where ERP rose. The sectors experiencing a rise in ERP account for $72.7 \%$ of GDP using 2000 values. However, in all cases the rise in protection reflects a reduction in negative ERP, i.e. they reflect a decline in distortions arising from liberalisation. The results of this analysis therefore strongly indicate that less of South African output is distorted by tariffs in 2004 than in 1993. A similar conclusion is reached when using collection rates, earlier base years and ERP excluding surcharges.

\section{(c) Sensitivity of ERP to non-tariff barriers in agriculture}

A critique of existing studies is that they do not take into account distortions arising from non-tariff barriers, which were particularly prevalent in agriculture during the early 1990s. To test the sensitivity of the results to non-tariff barriers, nominal protection on agricultural products in 1993 is raised by a multiple of 3 from $10.5 \%$ to $31.4 \%$ (using scheduled rates and including surcharges). The results for selected sectors are presented in Table 6.

Table 6. Sensitivity of ERP estimates using scheduled rates to non-tariff barriers in agriculture

\begin{tabular}{|c|c|c|c|c|c|c|}
\hline & \multicolumn{3}{|c|}{ Unadjusted } & \multicolumn{3}{|c|}{ Adjusted } \\
\hline & 1993 & 2004 & $\triangle$ ERP 93-04 & 1993 & 2004 & $\Delta$ ERP 93-04 \\
\hline Total excl. services & 41.8 & 11.0 & -21.7 & 39.8 & 11.0 & -20.6 \\
\hline Agriculture, forestry and fishing [1] & 10.0 & 1.7 & -7.5 & 48.7 & 1.7 & -31.6 \\
\hline Mining [2] & 2.3 & 0.2 & -2.0 & 2.3 & 0.2 & -2.0 \\
\hline Manufacturing [3] & 48.0 & 12.7 & -23.8 & 44.8 & 12.7 & -22.1 \\
\hline Services [4-9] & -5.5 & -2.2 & 3.6 & -5.6 & -2.2 & 3.6 \\
\hline \multicolumn{7}{|l|}{ Selection of other affected sectors } \\
\hline Food [301-304] & 85.5 & 38.4 & -25.4 & 26.7 & 38.4 & 9.2 \\
\hline Beverages [305] & 84.2 & 21.5 & -34.1 & 78.3 & 21.5 & -31.9 \\
\hline Tobacco [306] & 693.4 & 194.8 & -62.8 & 613.8 & 194.8 & -58.7 \\
\hline Textiles [311-312] & 183.3 & 52.3 & -46.3 & 164.7 & 52.3 & -42.5 \\
\hline
\end{tabular}

Notes: Total excl. services is calculated using 1993 GDP as weights.

Import weighted averages for manufacturing and mining are presented.

These results suggest that the failure to properly account for protection within agriculture during the early 1990s may actually bias the GDP weighted economy-wide average effective rate of protection upwards and not downwards as is frequently expected. While the estimated ERP in agriculture in 1993 rises from $10 \%$ to $48.7 \%$, protection in manufacturing declines from $48 \%$ to $44.8 \%$, largely in response to a decline in estimated protection within food $(85.5 \%$ to $26.7 \%)$. Estimated levels of ERP in other sectors that use agricultural products as intermediate inputs (beverages, tobacco and textiles) also decline.

\section{(d) Anti-export bias}

The analysis of nominal and effective rates of protection reveals changes in protection for domestic import-competing producers. This section analyses the effect of trade liberalisation on the competitiveness and profitability of export production.

Tariff protection raises the cost of intermediate inputs, which reduces the profitability of exports that are sold at world prices. Tariff liberalisation is therefore 
expected to have improved the profitability of export production, but this may have been offset by the phasing out of GEIS subsidies (Kuhn and Jansen, 1997). Alternative export incentive schemes (rebates, refunds and drawbacks of import duties on goods produced for exports) and WTO friendly supply-side export promotion schemes are available, although the number of firms that make use of these facilities appears low (WTO, 1998: 74; Chandra et al. 2001a, 2001b).

To evaluate the impact of tariff liberalisation on the relative incentive for export production, measures of the anti-export bias are calculated. Following Kuhn and Jansen (1997) and Van Seventer (2001), the anti-export bias (AEB) on product $j$ is measured as:

$$
A E B_{j}=\frac{1+E R P_{j}}{1+X R P_{j}}
$$

where XRP measures the costs associated with protection on intermediate goods as a share of world value added:

$$
X R P_{j}=\frac{\sum_{i} a_{i j} t_{i}}{1-\sum_{i} a_{i j}} .
$$

The anti-export bias thus measures the extent to which trade policies increase value added when a firm sells goods on the domestic market compared to export markets. Values in excess of 1 reflect a bias towards the domestic market.

Subsidies, tax rebates and exemptions lower the estimated $X R P_{j}$. To capture these effects, the export incentives arising from GEIS, drawback of duties, rebates of duties and transport costs are derived from the Kuhn and Jansen (1997) data for 1993, 1996 and 1999. The data for 1994 and 1995 are interpolated using compound growth rates. Data for 1998 and 2000-2004 are set equal to the period 1999, while 1997 is the average of 1996 and $1998 .{ }^{18}$

As shown in Table 7, tariff liberalisation has substantially reduced the implicit tax on export production. In 1993 the import weighted average anti-export bias in manufacturing fell from 2.6 in 1993 to 1.4 in 2004. Moderate declines in the antiexport bias were also experienced in mining and agriculture. At the sector level large declines were experienced in tobacco, textiles, wearing apparel, leather products and footwear. Nevertheless, relatively high levels of anti-export bias $(>1.9)$ remain in these sectors.

However, much of the decline in the anti-export bias during the early 1990s was offset by the phasing out of GEIS. After including the various export incentives, the average anti-export bias, weighted by imports, rose from 1.4 to 1.5 between 1993 and 1996. Further tariff liberalisation then reduced the anti-export bias to 1.3. Thus, the inclusion of export incentives suggests that there has been only a marginal improvement in the anti-export bias during the 1990s. This may explain South Africa's mediocre export performance compared with many other middle-income economies

\footnotetext{
18 A reasonably high correlation (0.66) is found between the derived export incentive values and export subsidy values obtained from GATT (1993).
} 
during the 1990s (Alves and Kaplan, 2004).

Table 7. Measures of anti-export bias using scheduled rates inclusive of surcharges

\begin{tabular}{|c|c|c|c|c|c|c|c|c|}
\hline & \multicolumn{4}{|c|}{ Excluding export incentives } & \multicolumn{4}{|c|}{ Including export incentives } \\
\hline & 1993 & 2000 & 2004 & Rank 2004 & 1993 & 2000 & 2004 & Rank 2004 \\
\hline Total & 2.1 & 1.3 & 1.3 & & 1.5 & 1.3 & 1.2 & \\
\hline Agriculture, forestry $\&$ fishing [1] & 1.2 & 1.1 & 1.1 & & 1.0 & 1.1 & 1.0 & \\
\hline Mining [2] & 1.1 & 1.0 & 1.0 & & 1.0 & 1.0 & 1.0 & \\
\hline Manufacturing [3] & 2.6 & 1.5 & 1.4 & & 1.4 & 1.4 & 1.3 & \\
\hline Services [4-9] & 1.0 & 1.0 & 1.0 & & 1.0 & 1.0 & 1.0 & \\
\hline Agriculture, forestry \& fishing [1] & 1.2 & 1.1 & 1.1 & 25 & 1.0 & 1.1 & 1.0 & 27 \\
\hline Coal mining [21] & 1.0 & 1.0 & 1.0 & 31 & 1.0 & 1.0 & 1.0 & 42 \\
\hline Gold \& uranium ore mining [23] & 1.2 & 1.0 & 1.0 & 31 & 1.1 & 1.0 & 1.0 & 43 \\
\hline Other mining $[22 / 24 / 25 / 29]$ & 1.1 & 1.0 & 1.0 & 29 & 1.0 & 1.0 & 1.0 & 28 \\
\hline Food [301-304] & 5.0 & 2.2 & 1.8 & 7 & 2.4 & 1.9 & 1.7 & 5 \\
\hline Beverages [305] & 3.3 & 1.4 & 1.4 & 10 & 1.2 & 1.2 & 1.1 & 18 \\
\hline Tobacco [306] & $>30$ & 5.2 & 4.2 & 1 & 25.5 & 5.2 & 4.4 & 1 \\
\hline Textiles [311-312] & $>30$ & 3.6 & 2.2 & 4 & 7.1 & 2.8 & 2.0 & 4 \\
\hline Wearing apparel [313-315] & $>30$ & 4.9 & 2.7 & 3 & $>30$ & 3.2 & 2.2 & 3 \\
\hline Leather \& leather products [316] & $>30$ & 2.2 & 1.9 & 6 & 2.0 & 1.6 & 1.5 & 8 \\
\hline Footwear [317] & 14.4 & 2.1 & 2.0 & 5 & 3.2 & 1.7 & 1.7 & 6 \\
\hline Wood \& wood products [321-322] & 1.9 & 1.3 & 1.3 & 13 & 1.3 & 1.2 & 1.2 & 12 \\
\hline Paper \& paper products [323] & 1.6 & 1.3 & 1.3 & 15 & 1.2 & 1.2 & 1.2 & 13 \\
\hline Printing \& publishing [324-326] & 1.6 & 1.1 & 1.1 & 22 & 0.9 & 1.0 & 1.0 & 26 \\
\hline Coke \& refined petroleum [331-333] & 1.4 & 1.2 & 1.1 & 23 & 1.2 & 1.1 & 1.1 & 23 \\
\hline Basic chemicals [334] & 1.4 & 1.1 & 1.1 & 26 & 1.1 & 1.0 & 1.0 & 25 \\
\hline Other chemicals [335-336] & 1.9 & 1.2 & 1.2 & 18 & 1.1 & 1.1 & 1.1 & 20 \\
\hline Rubber products [337] & 1.9 & 1.5 & 1.4 & 9 & 1.5 & 1.4 & 1.3 & 9 \\
\hline Plastic products [338] & 2.1 & 1.3 & 1.3 & 12 & 1.1 & 1.2 & 1.2 & 15 \\
\hline Glass \& glass products [341] & 1.6 & 1.2 & 1.2 & 17 & 1.3 & 1.2 & 1.1 & 16 \\
\hline Non-metallic minerals [342] & 1.5 & 1.1 & 1.2 & 20 & 1.4 & 1.1 & 1.1 & 19 \\
\hline Basic iron \& steel [351] & 1.4 & 1.2 & 1.2 & 19 & 1.2 & 1.2 & 1.1 & 17 \\
\hline Basic non-ferrous metals [352] & 1.4 & 1.1 & 1.1 & 27 & 1.3 & 1.1 & 1.0 & 24 \\
\hline Metal products [353-355] & 2.1 & 1.3 & 1.3 & 14 & 1.2 & 1.2 & 1.2 & 11 \\
\hline Machinery \& equipment [356-359] & 1.6 & 1.1 & 1.1 & 21 & 0.9 & 1.1 & 1.1 & 21 \\
\hline Electrical machinery [361-366] & 2.0 & 1.3 & 1.3 & 16 & 1.1 & 1.2 & 1.2 & 14 \\
\hline Communication equipment [371-373] & 3.4 & 1.1 & 1.1 & 24 & 1.6 & 1.1 & 1.1 & 22 \\
\hline Professional \& scientific [374-376] & 1.6 & 1.0 & 1.0 & 30 & 0.9 & 0.8 & 0.8 & 45 \\
\hline Motor vehicles [381-383] & $>30$ & 4.0 & 2.9 & 2 & 3.0 & 3.8 & 3.0 & 2 \\
\hline Other transport equipment [384-387] & 1.3 & 1.0 & 1.0 & 28 & 0.7 & 0.9 & 0.9 & 44 \\
\hline Furniture [391] & 2.8 & 1.8 & 1.7 & 8 & 1.8 & 1.6 & 1.6 & 7 \\
\hline Other manufacturing [392-393] & 1.6 & 1.4 & 1.3 & 11 & 1.6 & 1.4 & 1.3 & 10 \\
\hline
\end{tabular}

Notes: The export incentives are derived from the data presented in Kuhn and Jansen (1997). The antiexport bias for agriculture, mining, manufacturing and services are calculated using the average ERP and XRP at the SIC 1 digit level. The SIC 1-digit level values of ERP and XRP are in turn import weighted averages for manufacturing and mining, but are the simple average for the total economy and services.

\section{INTERNATIONAL COMPARISON}

In Table 8 average nominal MFN tariffs in SA are benchmarked against a range of countries and regions for which consistent data are available for at least a year in both 
periods $1993-95$ and $2002-04 .^{19}$

The data are obtained from the Trade Analysis and Information System (TRAINS) database. The difficulties surrounding the analysis of protection within a single country are compounded when comparing protection across various countries. In calculating the averages in Table 8, only the ad valorem tariffs are included and potentially high levels of protection from non-ad valorem (including mixed tariffs) are ignored. For example, the simple average for South Africa between 1993 and 95 rises from 16\% to $18.6 \%$ once ad valorem equivalents, as calculated in this paper, are included. Nevertheless, some insight on the relative level of protection and trend over time can be obtained through such comparisons.

As shown in Table 8, the level of protection in South Africa appears to be slightly lower than in other lower-middle-income countries, but is substantially higher than the average for high-income OECD countries. Looking at the change in tariffs, average protection has fallen in most regions, with particularly large declines occurring in lower-middle-income and low-income economies. While tariff protection has declined in South Africa (-4.9\%), is has not declined at a significantly faster pace than the average for other lower-middle-income economies $(-5.3 \%)$. These results suggest that the liberalisation process in South Africa has not been 'excessive' compared to its counterparts.

Table 8. Trends in average ad valorem tariff rates for selected countries and regions (\%)

\begin{tabular}{|c|c|c|c|}
\hline & $1993-95$ & 2002-04 & $\%$ change \\
\hline Australia & 8.8 & 4.2 & -4.2 \\
\hline Brazil & 13.3 & 13.5 & 0.2 \\
\hline Chile & 11.0 & 6.5 & -4.0 \\
\hline China & 37.3 & 10.9 & -19.2 \\
\hline European Union & 6.8 & 4.5 & -2.1 \\
\hline India ${ }^{a}$ & 47.8 & 29.1 & -12.6 \\
\hline Indonesia & 16.6 & 6.9 & -8.3 \\
\hline Japan & 4.4 & 3.6 & -0.7 \\
\hline Korea, Rep. & 9.1 & 12.7 & 3.3 \\
\hline New Zealand & 7.5 & 3.2 & -4.1 \\
\hline Nigeria & 26.9 & 30.0 & 2.4 \\
\hline SA (excl. ad valorem equivalents) & 16.0 & 10.3 & -4.9 \\
\hline SA (incl. ad valorem equivalents) & 18.6 & 10.3 & -7.0 \\
\hline Turkey & 9.4 & 10.0 & 0.5 \\
\hline United States & 5.4 & 3.8 & -1.5 \\
\hline \multicolumn{4}{|l|}{ Simple average by region } \\
\hline High-income, non-OECD & 7.8 & 5.4 & -2.3 \\
\hline High-income, OECD & 6.4 & 3.5 & -2.7 \\
\hline Lower-middle-income & 18.7 & 12.4 & -5.3 \\
\hline Low-income & 25.4 & 14.7 & -8.5 \\
\hline Upper-middle-income & 12.3 & 11.7 & -0.5 \\
\hline Observations & 69 & 69 & \\
\hline \multicolumn{4}{|l|}{ Rank (from high to low tariffs) } \\
\hline SA (excl. ad valorem equivalents) & 31 & 40 & 9 \\
\hline SA (incl. ad valorem equivalents) & 21 & 40 & 19 \\
\hline
\end{tabular}

Notes: Change in tariff is calculated as $\left(\mathrm{t}_{1}-\mathrm{t}_{0}\right) /\left(1+\mathrm{t}_{0}\right)$. The averages include agriculture, mining and manufacturing sectors. The data for South Africa is based on the MFN tariff schedule, excluding surcharges.

19 The results do not change substantially if the full sample of countries is used. 


\section{CONCLUSION}

This paper constructs a new data set to re-evaluate changes in nominal and effective protection of South African industries from the late 1980s. Estimates of protection are found to be sensitive to the use of collections duties or scheduled tariff rates, with the latter showing both a higher level of protection and greater decline in protection than the former. However, the structure of nominal and effective protection is relatively insensitive to the choice of tariff measure.

Estimates of the level of effective protection are also shown to be sensitive to the choice of Input-Output or Supply-Use table. Most estimates of effective protection in SA use a single table for the entire period of analysis. While this biases estimates of the level of protection, evidence suggests that the structure of protection across sectors and time is largely unaffected.

Failure to account for non-tariff barriers, that were particularly prevalent in agriculture during the early 1990s, also biases estimates of effective protection. However, the bias on the aggregate level of protection for the economy is not necessarily downwards. Sensitivity tests show that raising nominal protection on agriculture raises estimates of effective protection in agriculture, but lowers effective protection in manufacturing, particularly in those sectors such as food products that use agricultural products as intermediate inputs.

This paper also presents estimates of the anti-export bias arising from tariff protection. While tariff liberalisation has reduced the anti-export bias, the removal of export subsidies under GEIS has offset much of the gains. Further liberalisation may be required to improve the profitability of export production and hence export performance.

Finally, tariff liberalisation has led to significant reductions in the level of nominal and effective protection during the 1990s. Average nominal protection in manufacturing using scheduled rates and including surcharges fell from $22.9 \%$ in 1994 to $8.2 \%$ in 2004 . Effective protection in manufacturing fell from 48 to $12.7 \%$ over the same period. A decline in protection is also found if surcharges are excluded and collection duties rather than scheduled rates are used. Reductions in protection occurred in almost all traded sectors. The paper therefore finds that less output is subject to tariff distortions in 2004, than in the early 1990s.

However, further progress can be made. The tariff structure is still complex with a high number of tariff bands, domestic spikes and nuisance tariffs. High nominal and effective protection remains in sectors such as clothing, textiles, footwear and tobacco. Tariff protection also declined at no faster pace than in other developing or middleincome economies. Liberalisation has thus not been 'excessive' once benchmarked against comparator countries.

The availability of detailed tariff data over a number of years, as used in this study, now facilitates a more rigorous analysis of the impact of trade liberalisation on the South African economy. This hopefully is the direction of future research.

\section{REFERENCES}

Altman, M. (1994). An Industrial Strategy for the Clothing Sector. Cape Town: University of Cape Town Press.

Alves, P. and Kaplan, D. (2004). "South Africa's Declining Export Shares: The Developing Country Challenge." Trade and Industry Monitor, Vol. 30.

ANDERSON, J. (1998). "Effective protection redux." Journal of International Economics, 44: 21-44.

BALASSA, B. (1965). "Tariff Protection in Industrial Countries: An Evaluation,” Journal of Political Economy, 73: 573-594. 
BELL, T. (1992). "Should South Africa further liberalise its foreign trade?" Working paper no. 16, Economic Trends Research Group, Cape Town.

(1997). "Trade policy." In J. Michie and V. Padayachee, V. (eds.), The Political Economy of South Africa's Transition. London: Dryden press.

Belli, P., Finger, M. and Ballivian, A. (1993). "South Africa: A review of trade policies." World Bank Informal Discussion Papers on Aspects of the South African Economy no 4, The Southern Africa department, The World Bank. Central Statistical Services. (1993). Final Input-Output Tables 1988 (Report no. 04-02-02). Pretoria: Government Printers. (1995). Final Input-Output Tables 1993 (Report no. 04-02-03). Pretoria: Government Printers.

Chandra, V., MoOrty, L., Rajaratnam, B. and Schaefer, K. (2001a). "Constraints to growth and employment in South Africa: Statistics from the large manufacturing firm survey.” World Bank Informal Discussion Papers on Aspects of the South African Economy no. 14, The Southern Africa department, The World Bank.

Chandra, V., Moorty, L., Nganou, JP., Rajaratnam, B. and Schaefer, K. (2001b). "Constraints to growth and employment in South Africa: Evidence from the small, medium and micro enterprise firm survey." World Bank Informal Discussion Papers on Aspects of the South African Economy no. 15, The Southern Africa department, The World Bank.

CORDEN, WM. (1966). "The structure of a tariff system and the effective protection rate." Journal of Political Economy, 74: 221-237.

FEDDERKE, J. and VASE, P. (2001). "The nature of South Africa's trade patterns by economic sector, and the extent of trade liberalisation during the course of the 1990's." South African Journal of Economics, 69(3): 436-473. and __ (2004). "Response to Rangasamy and Harmse: Trade liberalisation in the 1990s." South African Journal of Economics, $72(2)$ : 407-412.

GreEnAWAy, D. and Milner, C. (1993). Trade and Industrial policy in developing countries. Basingstoke: Macmillan Press. and _ (2003). "Effective protection, policy appraisal and trade policy reform." Globalisation and Labour markets Research paper series 2003/06, University of Nottingham.

Holden, M. (1992). "The structure and incidence of protection in South Africa." In P. Black and B. Dollery (eds.), Leading Issues in South African Microeconomics. Johannesburg: Southern book publishers.

(2001). "Effective protection revisited: How useful a policy tool for South Africa?" South African Journal of Economics, 69 (4): 659-673.

HOLDEN, M. and HOLDEN, P. (1975). "An intertemporal calculation of effective rates of protection for South Africa." South African Journal of Economics, 43 (3): 370-79.

and _ (1978). "Factor substitution and the calculation of effective tariff rates." South African Journal of Economics, 46 (3): $225-234$

Industrial Development Corporation (1996) “The tariff rationalisation process." Presentation to Portfolio Committee on Trade and Industry, 30 September, IDC, Sandton.

(1990). “Ondersoek na die Tariefbeskermingsbeleid: Ontleding van die Tariefstruktuur.” Industrial Development Corporation, South Africa.

JANSEN, R. and JOUBERT, R. (1998). "Trade deflators: Towards disaggregated price indices of traded goods." Paper presented at the Trade and Industrial Policy Secretariat annual forum, Muldersdrift, September 1998.

Jenkins, C., Bleaney, M., Holden, M. and SiwisA, N. (1997). "A review of South Africa's trade policy." paper presented at the Trade and Industrial Policy Annual Forum, Muldersdrift, September 1997.

Jonsson, G. and Subramanian, A. (2000). "Dynamic gains from trade: Evidence from South Africa." International Monetary Fund Working Paper no. 00/45.

KuHN, G. and JANSEN, R., (1997). "The effective protection rate and anti-export bias." Industrial Development Corporation Technical Series, TS1/97.

PARIKH, A. (1979). "Forecasts of input-output matrices using the RAS method." Review of Economics and Statistics, 61: 477-81.

RANGASAmy, L. and HARmSe, C. (2003). "Revisiting the extent of trade liberalisation in the 1990s." South African Journal of Economics, 70 (4): 705-728.

Reserve BAnK. (Various years). Reserve Bank Quarterly Bulletin. Pretoria: South African Reserve Bank.

SEBONI, V. (2005). "Non-agricultural market access." Speech delivered by Deputy President of the Congress of South African Trade Unions to SANGOCO workshop on non-agricultural market access on 24 June 2005.

Statistics South AfricA. (1995). Input-Output Tables 1993 (Report no. 04-02-03). Pretoria: Government Printers. (1999). Final Supply and Use Tables 1993 (Report no. 04-04-01). Pretoria: Government Printers. (2001). Final Supply and Use Tables 1998 (Report no. 04-04-01). Pretoria: Government Printers. (2002). Final Supply and Use Tables 1999 (Report no. 04-04-01). Pretoria: Government Printers. (2003). Final Supply and Use Tables 2000 (Report no. 04-04-01). Pretoria: Government Printers.

TsiKATA, Y. (1999). "Liberalisation and trade performance in South Africa." World Bank Informal Discussion Papers on Aspects of the South African Economy no. 13, The Southern Africa department, The World Bank.

QUANTECH. (2004).S A Standardised Industry Database, Quantech Research. Available from http://www.tips.org.za/data/ VAN SEVENTER, DE. 2001. "The level and variation of tariffs rates: An analysis of nominal and effective tariff Rates in South Africa for the years 2000 and 2001." paper presented at the Trade and Industrial Policy Strategies Annual Forum, Muldersdrift, September 2001.

GATT. (1993). Trade Policy Review: South Africa. Geneva: General Agreement on Tariffs and Trade.

WTO. (1998). Trade Policy Review: Southern African Customs Union. Geneva: World Trade Organisation Secretariat. (2003). Trade Policy Review: Southern African Customs Union. Geneva: World Trade Organisation Secretariat. 